\title{
Определение последовательности кластера рДНК у японского перепела
}

\author{
Жукова А.А. ${ }^{*}$, Галкина С.А. ${ }^{2}$, Комиссаров А.С. ${ }^{3}$, Сайфитдинова А.Ф. ${ }^{1,4}$ \\ ${ }^{1}$ Российский государственный педагогический университет им. А.И.Гериена, Санкт-Петербург, Россия \\ ${ }^{2}$ Санкт-Петербургский государственный университет, Санкт-Петербург, Россия \\ ${ }^{3}$ Университет ИТМО, Санкт-Петербург, Россия \\ ${ }^{4}$ Международный изентр репродуктивной медииины, Санкт-Петербург, Россия \\ *e-mail: gatteriyagreen@gmail.com
}

Ключевые слова: ядрышковый организатор, рибосомные гены, нанопоровое секвенирование

Мотивация и цеель: Ядрышковые организаторы (ЯОР) представляют собой участки генома, содержащие повторяющиеся кластеры генов рибосомной РНК $(18 \mathrm{~S}, 5,8 \mathrm{~S}, 28 \mathrm{~S})$. Они играют важную роль в образовании ядрышек, где происходит сборка субъединиц рибосом. Среди птиц на настоящий момент полная информация об организации кластера генов рРНК есть только для курицы [1]. Эта последовательность может служить референсной для сборки ЯОР других видов птиц за исключением видов, в кариотипе которых произошли структурные изменения, затрагивающие ЯОР. Кариотип японского перепела Coturnix japonica, в отличие от большинства птиц, имеет три пары ядрышкообразующих хромосом [2]. У этого вида, помимо анцестрального интерстициального ЯОР на хромосоме 16 , имеются еще два терминальных ЯОР на коротких плечах акроцентрических хромосом, образование которых могло быть связано с активностью мобильных элементов [3]. Цель настоящего исследования - определить последовательность кластера рибосомных генов $C$. japonica на основе длинных прочтений.

Meтоды и алгоритмы: Для анализа были использованы прочтения, полученные в результате нанопорового секвенирования соматической геномной ДНК C. japonica на приборе MinION (Oxford Nanopore Technologies). Выравнивание проводили с использованием последовательности рДНК домашней курицы (MG967540.1), что позволило определить границы между генами и спейсерами. В работе использовали инструменты BLAST, Homology segment analysis и Geneious.

Результаты: Был собран фрагмент кластера генов рРНК японского перепела длиной 13189 п.н., включая: ETS - 1298 п.н., 18S - 1777 п.н., ITS1 -1992 п.н., 5,8S- 157 п.н., ITS2 - 633 п.н., 28S - 4572 п.н., ETS - 2760.

Bblвoдbl: Полученная консенсусная последовательность может использоваться в качестве референсной при поиске полиморфных участков рДНК японского перепела и идентификации кластеров, локализованных на других хромосомах.

Благодарности: При выполнении работы была использована инфраструктура Ресурсного центра «ЦКП Хромас» Научного парка СПбГУ.

\section{Список литературь}

1. DyominA.G. et al. 2016. PLoS ONE, 11(6): e0157464. doi:10.1371/journal.pone.0157464.

2. McPherson M.C.et al. 2014. Chromosome Research, 22(1):71-83. doi:10.1007/s10577-014-9411-2.

3. Saifitdinova et al. 2019. Molecular Cytogenetics, 12(30):63. doi:10.1186/s13039-019-0439-z. 